OPEN ACCESS

Edited by: Rajeev K. Singla,

Sichuan University, China

Reviewed by:

Mark Pfuhl,

King's College London,

United Kingdom

Godwin Upoki Anywar.

Makerere University, Uganda

*Correspondence:

Vivek P. Chavda

vivek7chavda@gmail.com https://orcid.org/0000-0002-7701-

8597

tThese authors have contributed equally to this work

Specialty section: This article was submitted to

Ethnopharmacology,

a section of the journal

Frontiers in Pharmacology

Received: 29 April 2021

Accepted: 21 July 2021

Published: 17 August 2021

Citation:

Chavda VP, Ertas YN, Walhekar V, Modh D, Doshi A, Shah N, Anand K

and Chhabria M (2021) Advanced

Computational Methodologies Used in

the Discovery of New Natural

Anticancer Compounds.

Front. Pharmacol. 12:702611.

doi: 10.3389/fphar.2021.702611

\section{Advanced Computational Methodologies Used in the Discovery of New Natural Anticancer Compounds}

\author{
Vivek P. Chavda ${ }^{1 *}$, Yavuz Nuri Ertas ${ }^{2,3}$, Vinayak Walhekar ${ }^{4 \dagger}$, Dharti Modh ${ }^{4 \dagger}$, Avani Doshi, \\ Nirav Shah ${ }^{6}$, Krishna Anand ${ }^{7}$ and Mahesh Chhabria ${ }^{8}$ \\ ${ }^{1}$ Department of Pharmaceutics and Pharmaceutical Technology, L.M. College of Pharmacy, Ahmedabad, India, ${ }^{2}$ Department of \\ Biomedical Engineering, Erciyes University, Kayseri, Turkey, ${ }^{3}$ ERNAM-Nanotechnology Research and Application Center, Erciyes \\ University, Kayseri, Turkey, ${ }^{4}$ Department of Medicinal Chemistry, Bharati Vidyapeeth's Poona College of Pharmacy, Pune, India, \\ ${ }^{5}$ Department of Chemistry, SAL Institute of Pharmacy, Ahmedabad, India, ${ }^{6}$ Department of Pharmaceutics, SAL Institute of \\ Pharmacy, Ahmedabad, India, ${ }^{7}$ Faculty of Health Sciences and National Health Laboratory Service, Department of Chemical \\ Pathology, School of Pathology, University of the Free State, Bloemfontein, South Africa, ${ }^{8}$ Department of Pharmaceutical \\ Chemistry, L.M. College of Pharmacy, Ahmedabad, India
}

Natural chemical compounds have been widely investigated for their programmed necrosis causing characteristics. One of the conventional methods for screening such compounds is the use of concentrated plant extracts without isolation of active moieties for understanding pharmacological activity. For the last two decades, modern medicine has relied mainly on the isolation and purification of one or two complicated active and isomeric compounds. The idea of multi-target drugs has advanced rapidly and impressively from an innovative model when first proposed in the early 2000s to one of the popular trends for drug development in 2021. Alternatively, fragment-based drug discovery is also explored in identifying target-based drug discovery for potent natural anticancer agents which is based on well-defined fragments opposite to use of naturally occurring mixtures. This review summarizes the current key advancements in natural anticancer compounds; computer-assisted/fragment-based structural elucidation and a multi-target approach for the exploration of natural compounds.

Keywords: natural anticancer compounds, theranostics, multi-target approach, fragment-based screening, drug antibody conjugate, drug repurposing, personalized medicine

\section{INTRODUCTION}

Cancer is a disorder in which cells proliferate abnormally deprived of control. These cancerous cells can attack other nearby tissues and transfer to other body parts via lymph and blood. Numerous types of cancers exist such as carcinoma (cancer of the skin or internal organs covering the tissues), leukemia (cancer of tissue that forms blood like, bone marrow, which leads to the production of too many defected blood cells), sarcoma (cancer of muscle, bone, fat, cartilage, blood vessels or other connective tissues or supportive tissues), lymphoma and multiple myeloma (cancer of the immune system cells) (NIH, 2021). Healthy cells can change into tumor cells by following the multiple-stage processes resulting from the interaction between genetic factors of the person and external parameters. These external parameters include physical carcinogens, for example, UV and ionizing radiation, chemical carcinogens like asbestos, constituents of tobacco smoke, food 
Globally reported New cases of Cancer in 2020


Stomach

$\square$ Cervix uteri

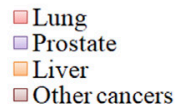

Globally reported Deaths due to Cancer in 2020

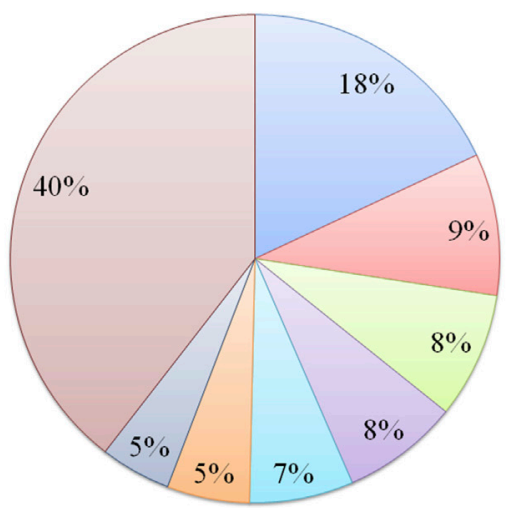

$\begin{array}{ll}\square \text { Lung } & \square \text { Colorectum } \\ \square \text { Liver } & \square \text { Stomach } \\ \square \text { Breast } & \square \text { Oesophagus } \\ \square \text { Pancreas } & \square \text { Other cancers }\end{array}$

FIGURE 1 | Statistics of globally reported cases and deaths due to various types of cancers in 2020 [Data Collected from (WHO, 2021 a)].

contaminants (aflatoxin), drinking water contaminants (arsenic), and biological carcinogens such as infection of virus, bacteria, or parasites (Setlow, 2001). Globally, cancer is the second major reason for mortality with an estimate of 10 million deaths in 2020 (Figure 1) among which, breast, lung, colon, rectal, prostate, skin, and stomach cancers were the most frequently observed. Lung cancer was responsible for the majority of cancer-related deaths in 2020 (WHO, 2021b). Throughout the globe, about 1 out of 6 deaths occur because of cancer each year. In low and middleincome countries, almost $70 \%$ of the deaths arise due to cancer, out of which, one-third of fatalities are caused by consumption of tobacco and alcohol, high body mass index, less intake of fruits and vegetables, and insufficient physical activity (Wogan et al., 2004). Several infections including human papillomavirus, $H$. pylori, Epstein-Barr virus, hepatitis $B$ virus, and hepatitis $C$ virus (HBV and $\mathrm{HCV}$ ) can also become indirect risk factors for cancer.

Advancements in multimodal imaging, 3D visual technology, combinational therapy, and the use of nanomedicine have improvized the effectiveness of cancer treatment in the past 2 decades (Shi et al., 2017; Chavda et al., 2019). Progress in cancer immunotherapy, chemotherapy, gene therapy, and epigenome therapy enables substantial improvement in cancer management. Apart from that surgeries including plastic surgery, robotic laparoscopy, radiotherapy, hormonal (mainly for breast and prostate cancer), and photothermal (laser) therapy has revolutionized cancer management (Kumar, 2018). The discovery of targeted drugs, monoclonal antibodies, checkpoint inhibitors, cancer vaccines (prophylactic and therapeutic), cytokines (interferon and interleukins), and chimeric antigen receptor T-cell (CAR-T cell) therapy is proven to be safe and effective in cancer management. Proton therapy is effective in the treatment of several cancer types such as brain, prostate, liver, lung, esophagus, breast, colon, eye, neck, and head. Advancements in robotic surgery enabled the treatment of certain cancers such as kidney, bladder, prostate, ovaries, throat, and uterus (Charmsaz et al., 2018). Many trials and research are ongoing in oncology for enhancing the efficacy of the treatment with minimum side effects.

Targeted drug delivery has proven effective in the treatment of various cancers with fewer side effects. Trastuzumab is used for breast cancers with human epidermal growth factor receptor 2 (HER-2) gene mutation. Afatinib and cetuximab block epidermal growth factor receptor (EGFR), which supports the development of colorectal and lung cancers. Dabrafenib and vemurafenib treat melanomas having mutated BRAF genes. Even though such targeted therapies are promising, currently they are used in very few types of cancers. Research towards improving such therapies is ongoing (Charmsaz et al., 2018). Multi-target therapy (either in sequential order or in combination) is also a widely used approach especially in the cases of intrinsic and acquired resistance towards anti-cancer compounds (Holohan et al., 2013). Drugs such as sunitinib, sorafenib, vandetanib, pazopanib, and axitinib are examples of multi-target treatment of cancer. Sunitinib is approved to treat gastrointestinal stromal tumors and renal cancer. Similarly, sorafenib is approved for renal cancer and liver cancer, where both drugs have the potential to target multiple sites. Vandetanib, pazopanib, and axitinib are used for treating non-small-cell lung cancer (NSCLC) and breast cancer. Vandetanib is effective in thyroid cancer, pazopanib in ovarian and kidney cancer, and axitinib in renal and pancreatic cancer (Petrelli and Valabrega, 2009).

Approximately $60 \%$ of effective anticancer drugs are obtained from natural sources (Newman and Cragg, 2012). Campothesins, nucleosides, taxanes, and vinca alkaloids are widely used anticancer drugs obtained from natural origin, and these can provide potential clinical efficiency with diminished toxicity. Another important chemotherapeutic anticancer role is offered by combining potent cytotoxic natural compounds with monoclonal antibodies, 
TABLE 1 | Pharmacological and Pharmacognostic details of the naturally occurring anticancer compounds.

\begin{tabular}{|c|c|c|c|c|}
\hline $\begin{array}{l}\text { Active chemical } \\
\text { constituents }\end{array}$ & $\begin{array}{l}\text { Plant name and } \\
\text { (plant family) }\end{array}$ & Mechanism of action & Biological target & References \\
\hline Shikonin & $\begin{array}{l}\text { Lithospermum erythrorhizon } \\
\text { Siebold and Zucc. } \\
\text { (Boraginaceae) }\end{array}$ & Cell proliferation and cell death & Inhibition of CDC25 and CDK1 & Zhang et al. (2019) \\
\hline Columbianadin & $\begin{array}{l}\text { Angelica decursiva (Miq.) } \\
\text { Franch. \& Sav. } \\
\text { (Apiaceae or Umbelliferae) }\end{array}$ & Angiogenesis & Inhibition of VEGF,EGF,PDGF, TNF- $\alpha$ & $\begin{array}{l}\text { Majnooni et al. } \\
\text { (2019) }\end{array}$ \\
\hline Polyphyllin D & $\begin{array}{l}\text { Paris polyphylla Sm. } \\
\text { (Melanthiaceae) }\end{array}$ & Apoptosis & $\begin{array}{l}\text { Inducing DNA fragmentation and phosphatidyl- } \\
\text { serine (PS) externalization }\end{array}$ & $\begin{array}{l}\text { Cheung et al. } \\
(2005)\end{array}$ \\
\hline Tanshinol A & $\begin{array}{l}\text { Salviae miltiorrhizae Bunge } \\
\text { (Lamiaceae) }\end{array}$ & $\begin{array}{l}\text { Inducing autophagy and apoptosis } \\
\text { and inhibiting cell growth and } \\
\text { migration }\end{array}$ & $\begin{array}{l}\text { Activating AMPK and inhibiting PI3K/Akt/mTOR } \\
\text { signaling pathway }\end{array}$ & Tay et al. (2019) \\
\hline Artesunate & $\begin{array}{l}\text { Artemisia annua L. } \\
\text { (Asteraceae) }\end{array}$ & $\begin{array}{l}\text { Apoptosis, arrest of the cell cycle at } \\
G_{0} / G_{1} \text {, and oxidative stress }\end{array}$ & $\begin{array}{l}\text { Regulating the pathway of NK-B, survivin, NOXA, } \\
\text { hypoxia-inducible factor- } 1 \alpha \text {, and BMl-1 }\end{array}$ & Das (2015) \\
\hline Dihydroartemisinin & $\begin{array}{l}\text { Artemisia annua L. } \\
\text { (Asteraceae) }\end{array}$ & Inhibition of tumor hypoxia & $\begin{array}{l}\text { Altering the ROS- dependent apoptosis which } \\
\text { summarises the activation of pro-apoptotic Bcl-2 } \\
\text { family member Bax, and caspase-activation }\end{array}$ & $\begin{array}{l}\text { Ontikatze et al. } \\
\text { (2014) }\end{array}$ \\
\hline Phenethyl isothiocyan & $\begin{array}{l}\text { Cruciferous vegetables } \\
\text { (Cruciferouceae) }\end{array}$ & $\begin{array}{l}\text { Inhibition of the progression of } \\
\text { tumorigenesis }\end{array}$ & $\begin{array}{l}\text { Pathway alteration of Akt, JNK, XIAP, MCl1, } \\
\text { BCL2, BCL-XL, BAD, BAX }\end{array}$ & Gupta et al. (2014) \\
\hline Piperlongumine & Piper longum L. (Piperaceae) & $\begin{array}{l}\text { Cell cycle arrest, inhibition of } \\
\text { angiogenesis, metastasis pathways, } \\
\text { and autophagy pathways }\end{array}$ & $\begin{array}{l}\text { Key regulatory proteins, including PI3K, AKT, } \\
\mathrm{mTOR}, \mathrm{NF}-\mathrm{k} \beta \text {, STATs, and cyclin D1 }\end{array}$ & $\begin{array}{l}\text { Tripathi and Biswal } \\
\text { (2020) }\end{array}$ \\
\hline Metformin & $\begin{array}{l}\text { Galega officinalis L. (Fabaceae } \\
\text { or Leguminosae) }\end{array}$ & Inhibition of tumor development & Triggering AMPK pathway & $\begin{array}{l}\text { Aljofan and } \\
\text { Riethmacher } \\
\text { (2019) }\end{array}$ \\
\hline Gossypol & genus Gossypium (Malvaceae) & Inhibition of tumor necrosis & Inhibition of TNF- $\alpha$ and NF- $\kappa \mathrm{B}$ & Lu et al. (2017) \\
\hline Anthocyanin & $\begin{array}{l}\text { Brassica oleracea var } \\
\text { (Brassicaceae) }\end{array}$ & Suppression of angiogenesis & Inhibition of TNF- $\alpha$, inducing VEGF expression & $\begin{array}{l}\text { Wang and Stoner } \\
(2008)\end{array}$ \\
\hline Paclitaxel & $\begin{array}{l}\text { Taxus brevifolia Nutt. } \\
\text { (Taxaceae) }\end{array}$ & $\begin{array}{l}\text { Arrest cells in the G2/M phase of the } \\
\text { cell cycle }\end{array}$ & Inhibition of EGFR & $\begin{array}{l}\text { Barbuti and Chen } \\
\text { (2015) }\end{array}$ \\
\hline Curcumin & $\begin{array}{l}\text { Curcuma longa L. } \\
\text { (Zingiberaceae) }\end{array}$ & $\begin{array}{l}\text { Inducing apoptosis and inhibiting } \\
\text { proliferation }\end{array}$ & Strong inhibition of TNF- $\alpha$ & $\begin{array}{l}\text { Barbuti and Chen } \\
\text { (2015) }\end{array}$ \\
\hline Dimethoxy curcumin & $\begin{array}{l}\text { Curcuma longa L. } \\
\text { (Zingiberaceae) }\end{array}$ & Anti-tumor effect & $\begin{array}{l}\text { Inhibition of EGFR, epithelial-mesenchymal } \\
\text { transition, and VEGFR }\end{array}$ & Chen et al. (2016) \\
\hline Curcuminoid B63 & $\begin{array}{l}\text { Curcuma longa L. } \\
\text { (Zingiberaceae) }\end{array}$ & Inducing cell proptosis & $\begin{array}{l}\text { Targeted TrxR1 protein and increases (ROS) level } \\
\text { which responsible for MAPK pathway activation. }\end{array}$ & Chen et al. (2019) \\
\hline Celastrol & $\begin{array}{l}\text { Tripterygium wilfordii Hook.f. } \\
\text { (Celastraceae) }\end{array}$ & $\begin{array}{l}\text { Suppressing the development and } \\
\text { progression of tumor }\end{array}$ & $\begin{array}{l}\text { Multiple signaling pathways inhibition such as } \\
\text { reactive oxygen species (ROS)/JNK and Akt/ } \\
\text { mTOR, NF-кb, STAT3/JAK2, HSP90, Cdc37, } \\
\text { p23, Iккb, p-Akt, ERa }\end{array}$ & Shi et al. (2020) \\
\hline Ginsenoside Rh2 & Panax spp (Araliaceae) & $\begin{array}{l}\text { Inhibition of cell proliferation, cell cycle, } \\
\text { cell invasion, and metastasis }\end{array}$ & $\begin{array}{l}\text { Signaling pathway inhibition Akt/mTOR, NF-кb, } \\
\text { STAT3 }\end{array}$ & Li et al. (2020) \\
\hline Hesperidin & Citrus aurantium L (Rutaceae) & $\begin{array}{l}\text { Responsible for autophagy and } \\
\text { apoptosis cell death, }\end{array}$ & $\begin{array}{l}\text { The regulatory protein of Caspase } 3 \text { and Aurora- } A \\
\text { kinase }\end{array}$ & Korga et al. (2019) \\
\hline $\begin{array}{l}\gamma \text {-tocotrienol, delta- } \\
\text { tocotrienol }\end{array}$ & $\begin{array}{l}\text { Elaeis guineensis Jacq. } \\
\text { (Arecaceae) }\end{array}$ & Inhibition of angiogenesis & $\begin{array}{l}\text { Downregulation of NF-kappa B pathway and } \\
\text { VEGF }\end{array}$ & Ling et al. (2012) \\
\hline Withaferin A & $\begin{array}{l}\text { Withania somnifera (L.) Dunal } \\
\text { (Solanaceae) }\end{array}$ & $\begin{array}{l}\text { Inhibition of angiogenesis and } \\
\text { inducing intratumoral apoptosis }\end{array}$ & $\begin{array}{l}\text { Encouraging the expression of pro-apoptotic } \\
\text { protein Bax and NF-kB pathway inhibiting by } \\
\text { caspase- } 3 \text { protein }\end{array}$ & $\begin{array}{l}\text { Lee and Choi } \\
(2016)\end{array}$ \\
\hline 6-Shogaol & $\begin{array}{l}\text { Zingiber officinale Roscoe } \\
\text { (Zingiberaceae) }\end{array}$ & Inducing apoptosis & Blocking of NF-kB & Ling et al. (2010) \\
\hline Berberine & $\begin{array}{l}\text { Berberis aetnesis aetnensis } \\
\text { C.Presl (Berberidaceae) }\end{array}$ & Inhibition of cell proliferation & $\begin{array}{l}\text { Suppressing EMT and downregulating signaling } \\
\text { pathways (ROS, inhibiting mTOR and Akt } \\
\text { phosphorylation, AMPK) }\end{array}$ & Wang et al. (2020) \\
\hline Honokiol & $\begin{array}{l}\text { Magnolia virginiana L. } \\
\text { (Magnoliaceae) }\end{array}$ & Regulation of cellular homeostasis & Downregulating signaling pathway AMPK/mTOR & Lee et al. (2019) \\
\hline Sanguinarine & $\begin{array}{l}\text { Argemone mexicana L. } \\
\text { (Papaveraceae) }\end{array}$ & $\begin{array}{l}\text { Inducing apoptosis and programmed } \\
\text { cell death }\end{array}$ & Inhibition of $\mathrm{Bax}$ and $\mathrm{Bcl}-2$ proteins & Xu et al. (2012) \\
\hline
\end{tabular}

Abbreviations: CDC, Complement-dependent cytotoxicity; CDK, Cyclin-dependent kinase; VEGF, Vascular endothelial growth factor; EGF, Endothelial growth factor; PDGF, Plateletderived growth factor; TNF- $\alpha$, Tumor necrosis factor-alpha; AMPK, AMP-activated protein kinase; mTOR, The mechanistic target of rapamycin; DNA, Deoxyribonucleic acid; BMI-1, Polycomb complex protein; ROS, Reactive oxygen species; Akt, Protein kinase B; JNK, c-Jun N-terminal kinases; STATs, signal transducer and activator of transcription proteins; MAPK, mitogen-activated protein kinase; NF- $\kappa B$, nuclear factor kappa-light-chain-enhancer of activated $B$ cells. 
TABLE 2 | Novel natural anticancer drug development approaches.

\begin{tabular}{|c|c|c|c|c|c|}
\hline Methods & Natural ligands & Targeted PDB ${ }^{a}$ & Activity & $\begin{array}{c}\text { Analytical } \\
\text { tools/Methodology }\end{array}$ & References \\
\hline \multirow[t]{4}{*}{$\begin{array}{l}\text { Structure-based } \\
\text { and Ligand-based }\end{array}$} & Porphyrin derivatives & $\begin{array}{l}\text { Interaction with Bcl2 active } \\
\text { site (PDB: 1XJ) }\end{array}$ & Antitumor activity & $\begin{array}{l}\text { Molecular dynamics (MD), } \\
\text { Structure-based } \\
\text { pharmacophore modeling, } \\
\text { Molecular simulation (MS) }\end{array}$ & Arba et al. (2018) \\
\hline & $\begin{array}{l}\text { Curcuminoids, thiotryptophan, and } \\
\text { 4-phenoxyphenol derivative }\end{array}$ & $\begin{array}{l}\text { PDB of EGFR, MMP-9, } \\
\text { mTOR, PKC AKR1B10 } \\
\text { (PDB:1ZUA) }\end{array}$ & Antitumor activity & Molecular docking & Parsai et al. (2014) \\
\hline & $\begin{array}{l}\text { Pheophytin [high affinity human } \\
\text { mitochondrial translocator protein } \\
\text { (TSPO) ligand] }\end{array}$ & $\begin{array}{l}\text { Inhibit mitochondrial } \\
\text { membrane Potential in } \\
\text { adenocarcinoma A549 cells }\end{array}$ & Cell survival & Molecular docking & Shailaja et al. (2019) \\
\hline & 4-Methylpteridinones (berberin) & PI3K/mTOR (PDB: 3OAW) & Cell survival & Molecular dynamics & Liu et al. (2010) \\
\hline Fragment-based & $\begin{array}{l}\text { Trypanosomabrucei, } \\
\text { Trypanosomacruzi, } \\
\text { Leishmaniainfantum, and } \\
\text { Plasmodium falciparum. }\end{array}$ & $\begin{array}{l}\text { Thioredoxin peroxidase } 2 \\
(T r x-P x 2)\end{array}$ & Antitumor activity & Molecular docking & Boucher et al. (2006) \\
\hline $\begin{array}{l}\text { Drug repositioning } \\
\text { and purposing }\end{array}$ & Metformin and Aspirin & $\begin{array}{l}\text { In-Vivo cell line MCF-7, } \\
\text { VEGFR-2 (PDB: 3ewz) }\end{array}$ & $\begin{array}{l}\text { Inhibition of breast } \\
\text { cancer cells }\end{array}$ & $\begin{array}{l}\text { Molecular dynamics and } \\
\text { Molecular simulation }\end{array}$ & Amaral et al. (2018) \\
\hline based & Mushrooms & $\begin{array}{l}\text { Inhibition of Histone } \\
\text { deacetylase (HDAC) } \\
\text { (PDB: } 3 \mathrm{C10})\end{array}$ & $\begin{array}{l}\text { Inhibition of breast } \\
\text { cancer cells (MCF-7 } \\
\text { cell line inhibition) }\end{array}$ & Molecular docking & Maruca et al. (2020) \\
\hline $\begin{array}{l}\text { Antibody-drug } \\
\text { conjugation }\end{array}$ & Gemtuzumab ozogmicin & $\begin{array}{l}\text { Calichemicin monoclonal } \\
\text { antibody }\end{array}$ & $\begin{array}{l}\text { Inhibition of cytotoxic } \\
\text { tumor }\end{array}$ & Disulfide-thiol exchange & Mullard (2014b) \\
\hline $\begin{array}{l}\text { Molecularly } \\
\text { targeted drug }\end{array}$ & Hematoxylin analogs & $\begin{array}{l}\text { Protein tyrosine kinase } \\
\text { inhibitor (VEGFR-r PDB: } \\
\text { 4ASD) }\end{array}$ & $\begin{array}{l}\text { Inhibition of } \\
\text { angiogenesis }\end{array}$ & $\begin{array}{l}\text { Molecular dynamics and } \\
\text { molecular simulation }\end{array}$ & $\begin{array}{l}\text { Ortiz-Hidalgo and } \\
\text { Pina-Oviedo (2019) }\end{array}$ \\
\hline $\begin{array}{l}\text { Leveraging } \\
\text { cutting-edge } \\
\text { technologies }\end{array}$ & Withaferin A & Cysteine 377 & $\begin{array}{l}\text { Inhibition of breast } \\
\text { cancer }\end{array}$ & In silico approaches & $\begin{array}{l}\text { Sivasankarapillai } \\
\text { et al. (2020) }\end{array}$ \\
\hline
\end{tabular}

${ }^{a} P D B:$ Protein Data Bank

particularly targeting antigenic determinant sites of tumors (Table 1) (Cragg and Pezzuto, 2016). Chemo-preventive and tumor-suppressive activities exerted by certain natural agents such as resveratrol, curcumin, indole-3-carbinol, (-)-epigallocatechin-3-gallate, and vitamin D have been reported in multiple studies (Weng et al., 2008; Chakraborti, 2011; Ko et al., 2017; Kwak et al., 2017; Tomeh et al., 2019).

Some natural products are also used to prevent severe side effects of chemotoxic agents which include nausea, vomiting, loss of appetite, diarrhea, constipation, fatigue, skin irritation, etc. Hence, the natural compounds obtained from plants, marine sources, bacteria, fungi, and animals have great potential to effectively target carcinogenic cells with minimal side effects. In this review, we discuss the potential of phytochemicals as anticancer agents followed by new computational approaches like multi-target and fragment-based approaches for the natural anticancer discovery and at last, we discuss theranostic role of natural anticancer agents.

\section{NATURAL ANTI-CANCER COMPOUNDS AND CURRENT RESEARCH}

Having extraordinary diversity in nature, the plant-derived compounds are recognized as rich sources of bioactives with some of them also possesses theranostic potential. In the past four decades, many efforts have been made to isolate new chemical entities (NCE) from natural sources like plants, marine, and microorganisms to develop anti-cancer agents. Since 1981, around $25 \%$ of new anticancer molecules are derived from natural sources but most of the targeted small molecules were launched after the year 1990 (Beck et al., 2017). Different approaches for the development of novel natural anticancer drugs are summarized in Table 2.

\section{a. Antibody-Drug conjugates}

The development of antibody-drug conjugation (ADCs) therapy in the early 1990's that integrates monoclonal antibody $(\mathrm{mAb})$ and potent chemotherapeutic agents in a single chemical moiety by a chemical linker has paved the way for the next-generation cancer therapeutics. This advanced approach explores targeting a mAb to improve tumor-specific drug delivery by the antigen-antibody interaction with enhanced anti-cancer activity. Physical and biological properties that are necessary for the ADCs are as follows: 1) Drug loading requires a suitable modified site for conjugation with $\mathrm{mAb}, 2)$ Appropriate solubility in water is crucial for desired antibody reaction, and 3) Considerably, higher toxicity $\left(\mathrm{IC}_{50}\right.$ between 0.01 and $0.1 \mathrm{nM}$ ) than the standard chemotherapeutic agents is required (Abdollahpour-Alitappeh et al., 2019). Gemtuzumab ozogamicin was the first approved conjugate of humanized 


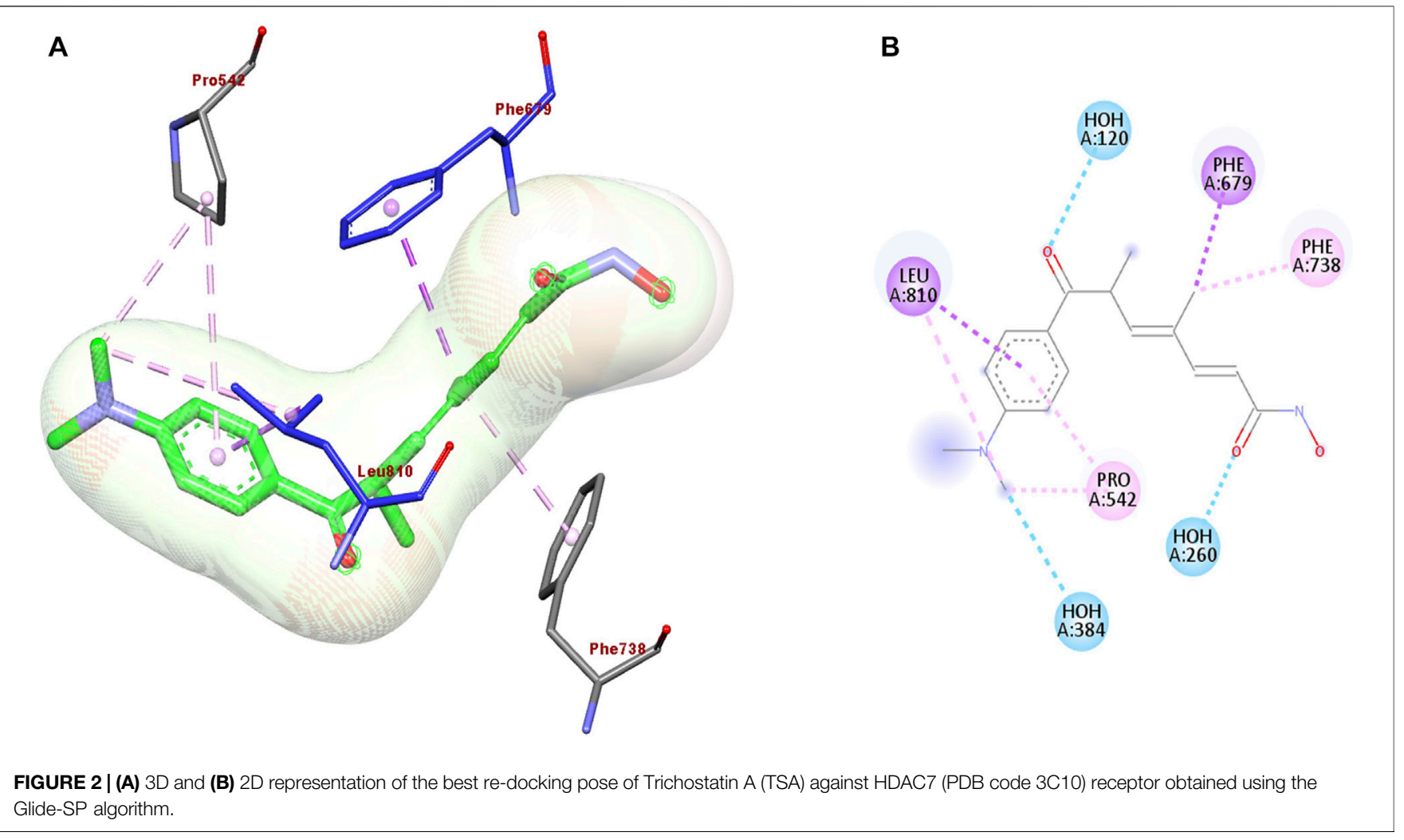

anti-CD33 monoclonal antibody which is covalently attached to the cytotoxic antitumor antibiotic calicheamicin, but it was withdrawn from the market in 2010 due to fatal adverse events like hemorrhage, infection, and/or acute respiratory distress syndrome. In 2011, brentuximab vedotin was approved for treating Hodgkin lymphoma and anaplastic large cell lymphoma (Mullard, 2014a).

\section{b. Structure-based drug design for natural products}

The structure-based drug design is a new approach that can be applied to naturally occurring molecules for the discovery of new anticancer agents. The application of such approaches, resulted in a substantial compilation of natural remedies with potential therapeutic activities against cancer which, while mostly immature as drug candidates, provide highly heterogeneous substrates for lead compounds. This is the most reliable approach for natural lead development. Hematoxylin and its analogs sourced from the heartwood of Haematoxylon campechianum L. manifested tyrosine kinase inhibitory potential (Lin et al., 2008).

\section{c. Drug mechanism-based evaluation of novel natural anticancer}

Cutting-edge technologies incorporated with chemoproteomics and multi-omics help to overcome challenges in the mechanistic investigation of naturally occurring drugs. Grossman et al. reported the use of chemoproteomics for the discovery of anti-cancer natural product withaferin A that targets cysteine 377 on the regulatory subunit PPP2R1A of the tumor suppressor protein phosphatase 2A complex, and impair breast cancer cell proliferation (Ward et al., 2019).

\section{d. Drug repositioning and repurposing}

The discovery of novel anticancer agents from natural sources remains a challenging task. Therefore, many of the currently used natural anticancer drugs are derived from already existing drugs used for the treatment of different diseases as a part of drug repurposing. Drug repositioning approaches include structure-based and ligand-based drug designs. Mushrooms display antifungal, antimicrobial, antiviral, antitumor, and antioxidant activities. The antifungal activity of the mushrooms also inhibits histone deacetylase (HDAC) resulting in anti-proliferative activity against human breast cancer cell line MCF-7. As demonstrated in Figure 2, Trichostatin A docking with HDAC 7 crystal structure of the protein (PDB: 3C10) shows interaction with LEU 810, PRO 542, PHE 738, PHE 679, HOH 260 , and $\mathrm{HOH} 384$ aminoacids by hydrogen and $\pi-\pi$ bond interaction (Maruca et al., 2020). Trichostatin A inhibits HDAC, resulting in anti-proliferative activity against the human breast cancer cell line, MCF-7. 


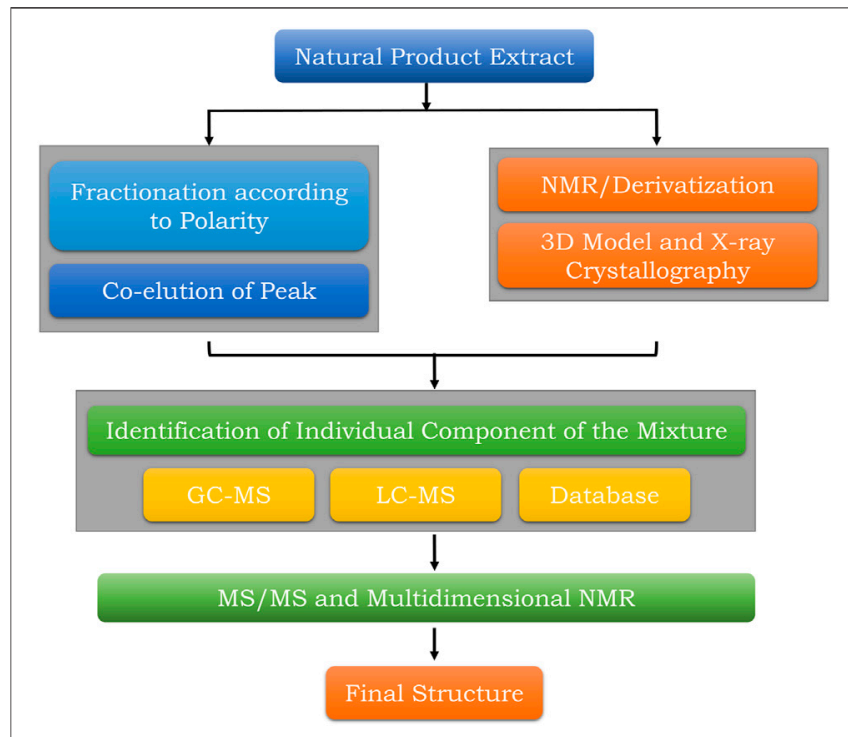

FIGURE 3 | Summary of stepwise structural elucidation techniques of natural products.

\section{COMPUTER ASSISTED STRUCTURAL ELUCIDATION OF NATURAL ANTICANCER COMPOUNDS AND OTHER BIOINFORMATICS APPROACHES}

The isolation and identification of natural compounds is a tedious task for chemists because natural compounds have more than one stereo-center, high molecular weight, and complicated chemical scaffolds (Koos et al., 2020). CASE strategies that are dependent on chromatographic and spectroscopic approaches are recently explored for structural elucidation of natural anticancer compounds (Elyashberg and Argyropoulos, 2020). However, to date, only a few spectral data are available for natural compounds, therefore structure elucidation remains a challenge. The spectroscopic and crystallographic analysis techniques accelerated the process of structural elucidation of natural molecules and helped in broadening the spectrum of structural elucidation that could be applied as a tool in the discovery of new drug entities (Nugroho and Morita, 2019).

Numerous advances in Mass Spectrometry (MS) and Nuclear Magnetic Resonance (NMR) over the last 2 decades have enabled structural elucidation processes for complex natural product mixtures (Figure 3). Qualitative analysis like MS gives information about the molecular weight and fragments of the sample. Recent scenarios of hyphenated techniques like LC-MS, GC-MS, GC-FID, GC-MSMS, and LC-MSMS are used for highresolution molecular weight determination with a decrease in the total number of overlapping $\mathrm{m} / \mathrm{z}$ ratios (Rinschen et al., 2019). Orthodox chromatographic approaches take a long time to identify or forecast the key chemical components found in a natural product mixture. The restricted compound references often render identifying or predicting each constituent in a mixture quite troublesome. As a result, an effective algorithm for solving the symmetric cone complementarity problem (CSCCP) is needed. Similarly, sensitive techniques like NMR spectroscopy give an essence of type and number of protons $\left(\mathrm{H}^{1}\right)$, carbon $\left(\mathrm{C}^{13}\right)$, phosphorous $\left(\mathrm{P}^{31}\right)$, and fluorine $\left(\mathrm{F}^{19}\right)$ content in the natural organic compounds. NMR spectrometric analysis alone cannot elucidate the structure of the natural organic compounds independently, therefore hyphenated techniques namely LC-NMR-MS and LC-UV-solid-phase extraction-NMR-MS are used. An IR spectrum can tell a lot about the existence or absence of such functional groups, but it does not give information about their environment in the compound (Elyashberg et al., 2009). It was suggested that 2D NMR data can be routinely generated, even in automation and a multitude of data are available as inputs to CASE systems like HSQC (HMQC), ${ }^{1} \mathrm{H}-{ }^{1} \mathrm{H}$ COSY (TOCSY), and HMBC methods (Elyashberg et al., 2009). Nowadays, 2D NMR spectroscopy is used for the structural elucidation and verification of natural organic molecules (Soong et al., 2020). A logical review of 2D NMR data often reveals the existence of "nonstandard" duration of COSY and HMBC correlations. Fuzzy structure generation allows for the right solution even though an uncertain number of nonstandard associations of unknown duration is present in the spectra (Su et al., 2017).

A new computer-aided software engineering (CASE) algorithm, known as the NP-Structure predictor, predicts individual components in a natural product mixture by using information acquired from LC-MS experiments (Harn et al., 2017). This is accomplished by comparing a list of known scaffolds with a list of weighted side groups to generate a list of potential molecules subject to defined structural constraints. They also mentioned an iterative DP algorithm with a wide range of potential sets of positions (Nk) that can be connected by the side chains upon its seed scaffolds, which may result in a challenging execution period for the algorithm (Kind and Fiehn, 2010; Harn et al., 2017). Expert system structure elucidator for the natural organic anticancer compound includes molecular connectivity diagram, structure generation, and verification and selection of the most probable structure. The fuzzy logic structure elucidator, which is based on spectral data, can easily identify large and complicated molecules consisting of up to 100 or more atoms with topological conceit. The beneficial predictions produced by computational models combined with empirical validations could help to accelerate the production of anti-cancer drugs from natural origin.

\section{FRAGMENT-BASED SCREENING OF NATURAL ANTICANCER COMPOUNDS}

Fragment-based drug discovery (FBDD) will have wide applications in the field of natural products in the upcoming years because extraction, isolation, and purification of the active constituents from the natural sources are quite tedious and timeconsuming (Khalifa et al., 2019). Application of in-silico techniques may expedite the process of development of potent and semisynthetic compounds that were originally isolated from natural sources. FBDD of the natural compounds is challenging 


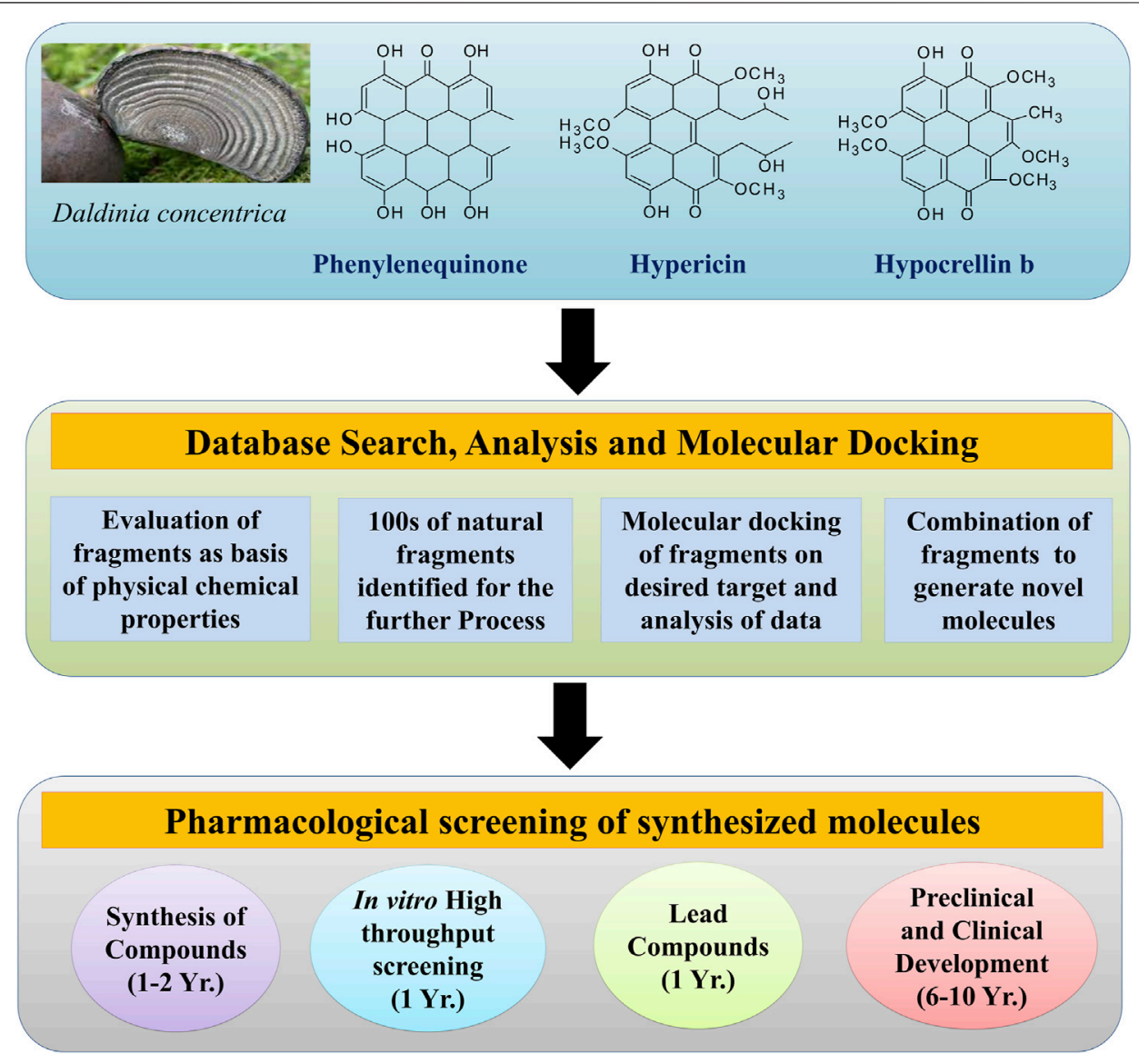

FIGURE 4 | Procedure for fragment-based screening.

because it is not yet largely explored for natural compounds manifesting anticancer activity (Murray and Rees, 2009). The natural chemical compounds that exhibit anticancer activity include alkaloids, polyphenolic compounds, etc. FBDD mainly depends on the molecular modeling strategy for the identification of the potential fragment for the anticancer agent. This involves the binding of the small fragments in the active site of the target (protein) to analyze the interaction of the small fragments with the target protein that helps the medicinal chemists and pharmacologists to design novel anticancer molecules. Natural anticancer compounds are sourced from plants, animals, and marine sources. The fragments are analyzed by various spectroscopic techniques and crystallographic techniques (David et al., 2020). Fragment-based screening (Figure 4) (Li, 2020) involves the following steps:

1. Collection of the compounds from the database

2. Filtration of the compounds from the database

3. Spectroscopic and crystallographic analysis of fragments

4. Molecular docking of the identified small fragments

5. Anti-cancer screening of the fragments.

Vemurafenib was the first drug discovered by the FBDD approach that consists of pyrollopyridine as a fragment for anticancer activity. Similarly, there is ample potential for various natural compounds to be screened as novel anticancer agents by applying the FBDD approach (Liu and Quinn, 2019). If a target has been established, bioinformatics can be used to comprehend the structure, which can be achieved by X-ray crystallography or other approaches such as homology modeling. The target protein would then be overexpressed. If the isotopically labeled protein is quickly purified and exhibits scattered cross-peaks in the $1 \mathrm{H}-15 \mathrm{~N}-\mathrm{HSQC}$ spectrum, this protein-based NMR can be used in screening. Otherwise, fragment scanning can be performed using DSF or 19F-NMR. If the target can be conveniently crystallized, X-ray crystallography would be the first tool to be used in screening. Where a target framework is open, the virtual screening will still be performed. An appropriate library would be chosen from a large number of sources, which is not a restriction. Structural, biophysical, and biochemical approaches can be used to validate the hits. Finally, appropriate techniques can be used to exploit fragment development (Figure 4). Role of medicinal chemists would be crucial in this phase.

Curcumin is an active constituent of Curcuma longa $\mathrm{L}$. (Family: Zingiberaceae), which exhibits anticancer activity. It consists of the active fragment of $\beta$-diketone. Curcumin's anticancer activities are due to its direct or indirect control of 
signal transduction pathways, via its effect on cell division, the p53 tumor suppressor gene, and transcription factors Nrf2 and $\mathrm{NFB}$, as well as modulation of inflammatory signaling cascades. Similarly, for the designing of novel COX-2 inhibitors like diketone, is a pharmacophore for developing anticancer agent (Kljun and Turel, 2017).

Potential natural anticancer compounds which act on p21activated kinase (PAK1) were reported by using computational methodologies (Shahinozzaman et al., 2020). 42 fragments of herbal compounds were identified from drugs such as triptolide, cucurbitacin I (C-I), nymphaeol A (NA), and staurosporine (SPN). Pharmacokinetic properties like absorption, distribution, metabolism, and excretion (ADMET) and molecular docking studies suggested that inhibitors C-I, NA, and SPN fit in the catalytic region of p21 activated kinase with promising pharmacological and pharmacokinetic parameters (Shahinozzaman et al., 2020). Molecular dynamic simulation studies revealed that NA shows tight binding with the PAK1 enzyme and can be considered to be safe while toxicity was manifested by SPN and C-I (Abdollahpour-Alitappeh et al., 2019).

AlAjmi et al. identified novel natural molecules as polo-like kinase (PLK-1) inhibitors with an anticancer activity using a computational modeling approach like FBDD (AlAjmi et al., 2018). Selleck's library of natural compounds was screened against PLK-1 with the aid of a molecular docking approach. Docking studies identified eight bioactive natural molecules (Apigenine, Dihydromyrecetion, Hesperidin, Hesperitine, Naringenin, Phlorizi, and Quesertine) as PLK-1 inhibitors. Molecular Mechanics-Generalized Born Surface Area (MMGBSA) calculations showed that hesperidin was found to be a potent inhibitor of PLK-1 by the formation of a sturdy complex with Tyrosine-protein kinase (TLK) and confirmed with the help of molecular dynamics simulation studies. The generated data provide ample evidence and confirmed that hesperidin is a potential PLK-1 inhibitor by following parameters as molecular weight $(610.56 \mathrm{~g} / \mathrm{mol}), 8$ H-bond donors, 15 H-bond acceptors, $234 \AA$ TpSA, 0 net charges, and 7 rotatable bonds. These results were more significant as compared to other natural inhibitors of PLK-1 as an anticancer agent. Similarly, optimization of natural compound Itampoli A as p38a inhibitor by application of FBDD approach was reported elsewhere (Liang et al., 2019). Itampoli A which is effective against lung cancer was isolated from Iotrochota purpurea, a marine sponge. Itampoli was modified with the aid of the FBDD strategy. A total of 45 brominated tyramine analogs were synthesized as fragments. In-vitro enzyme inhibition assay of 45 analogs was performed against the p38a enzyme. The inhibitory study revealed that (-)-itampolin A potentially inhibited p38a with an IC50 value of $7.9 \pm 1.7 \mathrm{nM}$. (-)-itampolin A also inhibited cell proliferation in the lung cancer cell line (A549) at a concentration of $0.66 \mathrm{mM}$. Molecular docking revealed that (-)-itampolin A fit in the active site of p38a by forming $3 \mathrm{H}-$ bonds with GLU71 and ASP168. On the other hand, the 3D QSAR approach revealed that the tyrosine skeleton was essential for the p38a inhibitory activity which was mainly contributed by the ureoid moiety in (-)-itampolin A (Liang et al., 2019).

Therefore, FBDD is one of the attractive tools for the medicinal scientists in order to explore natural anticancer agents and further identify hit fragments from the reported natural anticancer agents and model a new anticancer molecule (Koos et al., 2020).

\section{MULTI-TARGET APPROACH FOR THE EXPLORATION OF NATURAL ANTICANCER COMPOUNDS}

The conventional drug discovery approach was applied for the discovery of novel drugs. Even until 2000, scientists developed drugs separately for different targets of the same disease. This approach leads to an increase in the number of drugs and their corresponding side effects (Table 3). To avoid this, scientists focused on developing drugs that can target multiple sites of the same disease that can ultimately reduce the number of drugs in the chemical space and also the corresponding cost to develop them (Figure 5) (Ramsay et al., 2018). The blockbuster drug Sorafenib was developed by Bayers and Onyx which gained approval from USFDA in 2007. Sorafenib inhibited different kinases namely VEGFR-2, VEGFR-3, PDGFR $\beta$, c-Kit, and Raf, that play a crucial role in cancer progression and angiogenesis at a low nanomolar concentration. Similarly, in Indian traditional medicine, curcumin is a natural active constituent of crude drug turmeric and its semisynthetic analogs are used in the treatment of several types of cancers. In the last 3-4 decades, various drugs were developed which act by binding to diverse biological targets, resulting in desired pharmacological activity (Cragg and Pezzuto, 2016).

There are various targets for the treatment of different diseases like tyrosine kinase for cancer, cyclooxygenases (COX) for inflammation, and DNA gyrase for bacterial infection and tuberculosis. Marine plants are the main source of anticancer agents, and they can target more than one disease. Methanolic extract of Artemia salina is a marine brine shrimp that shows both anticancer as well as antibacterial activity. Natural antioxidants like selenium, vitamin E, myricetin, quercetin, and kaempferol act as anticancer agents via free radicals such as superoxide anion $\left(\mathrm{O}_{2}-\right)$, hydrogen peroxide $\left(\mathrm{H}_{2} \mathrm{O}_{2}\right)$, hydroxyl radicals (OH) (Kumar and Adki, 2018). Antibiotics like azithromycin, doxycycline, tigecycline, pyrvinium pamoate, chloramphenicol, 17-allylaminogeldanamycin, methotrexate, and anthracycline are principally used in the treatment of bacterial infections and manifest anticancer activity by inhibiting the cell growth on cell lines like MCF7, T47D, etc. at the concentration range of 50-200 nM.

Anti-inflammatory agents also act as anticancer agents by inhibiting various inflammatory mediators like TNF- $\alpha$, IL2 IL12, transforming growth factor beta (TGF- $\beta$ ), etc. Scientists have reported that COX2 and EGFR signaling is quite common to both cancer and inflammation, so COX2 inhibitors and the combination of both COX2 and EGFR inhibitors are potential anticancer agents at lower doses. COX2 enzyme has a crucial role 
TABLE 3 | Multitarget-based anti-cancer natural compounds.

Nature molecule/Crude drug

Anthracycline

Pyrano-quinolone

Taxol and Vinblastin

Deacetylnemorone

\section{References}

Cragg and Pezzuto (2016)

Kumar and Adki (2018)

Taylor et al. (2019)

Liu and Quinn (2019)
$\mathrm{PI} 3 \mathrm{~K}, \mathrm{APC}$, and RB signalling

SKMEL5 (melanoma cancer cells), MG-63 (osteosarcoma), SK-OV-3 (ovarian adenocarcinoma), MDA-MB-231 (breast cancer),

HCT 116 (colorectal carcinoma), HCT 116/200 (FdUrd resistant subclone of HCT 116 cells), A2780ADR (a doxorubicin-resistant subclone of the ovarian carcinoma A2780), and HUVEC (Normal human umbilical vein endothelial cells).

Curcumin NF-kB, miR-221, COX-2, and their effectors such as PTEN, p27, p57, and pro-inflammatory cytokines. STAT-1, STAT-3 phosphorylation, and Notch signaling pathway. Pancreatic cancer cell lines (MiaPaCa-2, Panc-1, AsPC-1, BxPC-3, and Pan02)

Curcumin

Piperine
COX-2, STAT-1 and STAT-3 signaling, NF-kB, VEFG, EGFR signaling, PI3/Akt, and m-TOR signaling, CDK, B-catenine, Tcf-4

Nuclear factor-kB (NF-kB), c-Fos, CREB, ATF-2, Melanoma cell line (B16F-10 piperine concentration = 2.5, 5, and $10 \mu \mathrm{g} / \mathrm{ml})$
Sahebkar (2016)

Sahebkar (2016)

Pradeep and Kuttan

(2004)



FIGURE 5 | Multitarget based screening of anticancer natural compounds. Pro-inflammatory mediators like TNF $\alpha$, JL2, JL12, etc. binds to the receptor on the cell surface which undergoes a conformational change and activates JNK 1/2. JNK1/2 phosphorylation leads to apoptosis that releases inflammatory factors like NFK $\beta$ that also releases inflammatory factors like TNF- $\alpha$ which plays role in cell death amplification. IL6 activates JAK/STAT pathway that results in cancer cell proliferation. TGFF $\beta$ also activates various pathways leading to liver fibrosis. EGFR binds to the cell surface receptor that activates GRB2. Phosphorylation of GRB2 activates the downstream pathway as GABI further activates P13K that activates AKT leading to cell survival. Natural fragments like indole, quinoline, isoquinoline, and piperidine inhibit both the inflammation pathway and EGFR in cancer cell growth. 
in tumor growth (Rayburn et al., 2009). Various natural alkaloids comprising indole, quinoline, isoquinoline, and piperidine manifests COX-2 inhibition (Figure 5). Pyrano-quinolone analogs also inhibit TNF-a and IL6 which are also proinflammatory mediators. Therefore, from the above discussion, it is clear that anti-inflammatory agents also act as anticancer agents (Dey et al., 2020).

Naturally occurring anti-mitotic agents like Nocodazole, Taxol, AZ138, BPR0L075, Vinblastine, Taxanes, and Epothilones, act by inhibition of PI3K and APC and RB pathways, and microtubule destabilizing agent which is related to the anticancer activity (Dall'Acqua, 2014). Dolastatin-10, Aplidine, Halichondrine- $B$, and Descodermolide inhibit the microtubule growth, ultimately, acting as anti-cancer agents. Therefore, from the above discussion, the naturally occurring compounds act by multi-targeting anticancer agents (Kumar and Adki, 2018).

Taylor et al. reported a rare natural product, Deacetylnemorone member of the diterpenoid family, as an anticancer agent which inhibits cell growth on different cancer cell lines (Taylor et al., 2019). Deacetylnemorone acts by resensitizing chemotherapy resistance of cancer. Activity reported for Deacetylnemorone is anti-angiogenic and cancer cell growth inhibitor. Curcumin was reported as a natural active constituent used in the treatment of pancreatic cancer by the multitarget approach. Curcumin inhibited various targets like NF- $\kappa$ B, miR-221, COX-2, and their effectors such as PTEN, p27, p57, and pro-inflammatory cytokines which ultimately causes cancer cell growth and progression (Sahebkar, 2016). Curcumin also inhibits phosphorylation STAT-1, STAT-3, and Notch signaling pathways which are responsible for pancreatic cancer cell growth. Reports also portray that curcumin is effective and selective towards different pancreatic cancer cell lines namely MiaPaCa-2, Panc-1, AsPC-1, BxPC-3, and Pan02.

Diederich et al. reported curcumin as a multitarget natural compound with its application in cancer interruption and therapy. Curcumin modulates numerous molecular targets and blocks signaling tracks such as COX-2, STAT, NF- $\kappa B$, VEGFR, EGFR, P13/Akt, and mTOR. It also influences cell cycle regulators like $\mathrm{CDK}, \mathrm{B}$-catenin, Tcf-4 for cancer progression (Teiten et al., 2010; Teiten et al., 2014). Curcumin activates the cancer cell death proteins, namely PARP, Bcl-2, Bcl-xL, LC-3II, and cyclin-B1. Curcumin and its analogs also act against diverse cancers like multiple myeloma, rectal cancer, pancreatic cancer, osteosarcoma, colon neoplasm, and colorectal cancer. Hence, curcumin is a multitargeting agent in cancer mitigation (Teiten et al., 2010).

Another study reported piperine as an anticancer agent which acts on various targets such as NF- $\mathrm{B}$, c-Fos, cAMP response element-binding protein (CREB), activated transcription factor 2 (ATF-2), and proinflammatory cytokine gene expression in B16F-10 melanoma cells. Piperine inhibited collagen matrix at a concentration of $2.5,5$, and $10 \mu \mathrm{g} / \mathrm{ml}$ against B16F-10 melanoma cells at a dose-dependent analysis (Pradeep and Kuttan, 2004). It also inhibited matrix metalloproteases with the aid of the zymographic method. Piperine restrained nuclear translocation of p65, p50, c-Rel subunits of NF- $\kappa B$ and other transcription factors such as ATF-2, c-Fos, and CREB that resulted in cancer growth inhibition (Pradeep and Kuttan, 2004).

\section{THERANOSTICS PERSPECTIVE OF NATURAL ANTICANCER COMPOUNDS}

Theranostics is the combination of diagnosis and treatments. It is a therapy in which a combination of one radioactive drug will diagnose the tumor and other radioactive drugs will treat the main tumor and metastatic tumors (Silva et al., 2019). This combination will diagnose cancer at various locations effectively and monitor the progress of the disease and guide for another treatment of chemotherapy or surgery whichever may be needed depending on the disease condition (Garofalo et al., 2020).

For many years, natural products have been used for their diverse chemical structures and unique targeted activities. Natural products are easily compatible with the human body and display low toxicity. Many natural products including porphyrins, perylene quinone derivatives, curcumin are photosensitizers and sono-sensitizers, which have been widely applied in fluorescence imaging, diagnosis, photodynamic therapy (PDT), and sonodynamic therapy (SDT) (Cova et al., 2019). In PDT, excited photosensitizers oxidize cellular macromolecules like nucleic acids and proteins, resulting in tumour cell apoptosis by producing reactive oxygen species. In SDT, ultrasound wave interacts with the water molecules in the environment, causing ultrasonic cavitation during which tiny cavities nucleate, grow, and collapse (Ma et al., 2019). Theranostic agents like porphyrin and its derivatives are approved for therapeutic usage in cancer management as they have lower toxicity and appropriate biocompatibility. Hematoporphyrin derivatives are photosensitizers, approved for clinical PDT. Porphyrinoid biohybrid materials are approved for phototheranostics. The light sensitivity of curcumin and its derivatives is weaker in the therapeutic window of wavelength, that limits their role as theranostic agents (de Araújo et al., 2020).

The theranostic role of SDT is only to tumorstastic action as it only inhibits the tumor growth especially of solid tumors. On the other hand, PDT has "-cidal effect" on the tumors. It is interesting to note here that to date, there is no SDT approved for the medicinal use however several photosensitizers are used for cancer management as a part of photodymanic therapy. The exact mechanism behind the SDT needs to be revealed soon, and natural SDT with better safety and efficacy in cancer management must be produced (Sharma et al., 2017).

Some of the examples of natural products used as theranostic agents are as follows:

- Porphyrin

- Perylene quinine (Hypocrellin, Hypericin, Cercosporin, Elsinochrome)

- Cercosporin

- Elsinochrome

- Curcumin

- Pheophytin 
- Psoralens

- Berberine chloride

- Graphene

Porphyrin, as a theranostic agent, has photodynamic, sonodynamic, and radiotherapeutic roles in the treatment of cancer. It is also used as a diagnostic agent for fluorescence imaging, magnetic resonance imaging, and photoacoustic imaging. The use of porphyrin is limited as a theranostic agent due to its poor selectivity for tumor cells. When nanoparticles are used as carriers of porphyrins, their anticancer effect improves. Perylene quinone has many pigments which show chemical and biological properties, making them diagnostic and therapeutic agents in PDT and SDT. Some pigments such as hypocrellins, elsinochrome, hypericin, cercosporin are included in perylenequinones. Hypocrellin, a pigment of perylenequinone category, is extracted and isolated from the Hypocrella bambusae, which is parasitic on Fargesia plant, has absorption between $400-800 \mathrm{~nm}$, and has a high oxygen species yield, making it suitable for the treatment of tumors. It is less toxic and has a fast metabolism rate in vivo, and it is one of the best-known new generation phototheronostic agents that has potential for the development of drugs (Bisen, 2016; Peyvandipour et al., 2018).

Cercosporin is a photodynamic photosensitive pereylene quinoline derivative that is often used with a co-polymer to target carcinogenic cells. Polymer releases cercosporin in acidic conditions and offers cancer treatment for patients. Elsinochrome is a theranostic agent showing photodynamic property which is used for targeted drug delivery to cancerous cells (Wilken et al., 2011).

Pheophytin, a form of seagrass, is a natural anticancer pigment that is evaluated in the management of adenocarcinoma A549 cells. Photo-reduction of pheophytin has been observed in various mixtures containing PSII reaction centers. Similarly, Psoralens (furanocoumarins) are explored for the treatment of certain lymphomas as targeted therapeutics in conjunction with ultraviolet rays (Shailaja et al., 2019).

Berberine chloride is an orally bioavailable, hydrochloride salt form of berberine, a quaternary ammonium salt of an isoquinoline alkaloid and active component of various Chinese herbs (Coptis chinensis French, Coptis deltoidea C. Y. Cheng et Hsiao and Coptis teetoides C. Y. Cheng) (Neag et al., 2018), with good anticancer, photodynamic, anti-inflammatory, and antilipidemic activities (Belwal et al., 2020). Berberines are isoquinoline derivatives and belong to protoberberines alkaloids. Berberine has been shown to have a major hormetic dose-response, where a low dose actively promotes the development of cancer cells whereas a high dose serves as an anticancer agent. Furthermore, because of its widespread presence in numerous plant species and low toxicity, berberine hydrochloride has the potential to be a powerful anticancer agent in the future (Singh and Sharma, 2018).

Graphene is an inorganic material that is used for making nanocomposites for drug delivery due to its lower toxicity and additional anticancer action (Hoseini-Ghahfarokhi et al., 2020). Apart from being an anticancer agent, the graphene is also has photodynamic action (Yang et al., 2019). Graphene is generally used as a nanocarrier for drug delivery, especially anticancer drug delivery (Jampilek and Kralova, 2021). The graphene nanocomposites have better drug loading and protective action, targeted delivery, are suitable for theranostic role, and have effective photodynamic action. It is used as a theranostic agent due to its anticancer action (Rosli et al., 2019).

\section{NATURAL ANTICANCER COMPOUNDS FOR PERSONALIZED MEDICINE}

There is substantial increase in our understanding of health and disease related aspects of human life due to technological advancement and multiomics approaches. To achieve proper effectiveness, the use of personalized pairings of precision targeted drugs recognized by proteogenomics will necessitate specialized modelling based on the latest methodologies ( $\mathrm{Li}$ and Bergan, 2020). Personalized medicine is a domain which aims to develop therapeutics for a single subject or group of subjects derived from current and past data capturing of physiological health and the environment exposure. Precision oncology has demonstrated some significant success in the last decade, despite the fact that it is expensive (Cutler, 2020). Consequently, the precision medicine approach, which was endorsed in 2015, has propelled the personalized medicine forward by necessitating the FDA to design new technologies for evaluating personalized medicine (Krzyszczyk et al., 2018).

Well over 700 natural compounds have now been confirmed to have pharmacological function, with many of them capable of targeting cellular processes or deregulated genes that inhibit tumorigenesis (Mazumder et al., 2018). For every cancer patient or group of patients, there is unique genetic makeup that serves as a cancer operator and can shift throughout therapy to stimulate response processes. When it is used in conjunction with certain drugs, several natural compounds with established molecular targets demonstrated good therapeutic benefits by restricting signalling proteins that facilitate tumor progression (Cerella et al., 2015). The continuously advancing domain of immunooncology has improved our understanding of tumorspecific immune responses as well as the ability of targeted chemotherapy drugs to stimulate the anti - tumor immunity toward carcinoma. It was recently noted that targeted therapies like oxaliplatin, that also kill cancer cells by triggering a host immune system, can make tumours more susceptible to checkpoint blockade treatment (Pfirschke et al., 2016). The distribution of key anti-apoptotic Bcl-2 proteins forecasted a complementary response (Mazumder et al., 2018). The brominated alkaloid isofistularin-3, derived from the marine sponge Aplysina aerophoba, is shown to suppress DNA methyltransferase (DNMT1) (Florean et al., 2016; Mazumder et al., 2018). In RAJI and U937 cells, isofistularin-3 combined with tumour necrosis factor related apoptosis inducing ligand (TRAIL) demonstrated strong synergy (Florean et al., 2016; Mazumder et al., 2018). Recently, it was observed that combining ursolic acid, curcumin, and resveratrol to locate STAT3, mTORC1, and AMPK action substantially lowered 
prostate cell proliferation and attenuated glutamine metabolism, thereby attacking a critical true sign of cellular kinetics (Kuntz et al., 2017).

Taken together, the important development of identified targeted agents of natural origin, as well as the immunogenic capability of such agents when combined with existing drugs, will contribute to future pharmacotherapy opportunities for tumour targeting.

\section{CONCLUSION AND FUTURE PROSPECTS}

For a long time, natural phytochemicals have been proven to be effective against different types of cancer. The opportunities and prospects of natural products for drug discovery are being significantly extended with the exploration of plant endophytic fungi, which have been recognized as a decent source of certain bioactive metabolites having an anticancer activity (Chandra, 2012). Major natural anticancer compounds like camptothecin, taxol, vinca alkaloids, and podophyllotoxin have been obtained from an endophytic fungus. Marine-derived bioactive compounds also have a large potential to produce an anticancer effect (Abdelmohsen et al., 2014). Similarly, bioactive metabolites from insects have potential for drug discovery in the rapidly growing areas of research like microbial genomics through genome mining and metagenomics (Bachmann et al., 2014; Charlop-Powers et al., 2014).

Drug research and production would necessitate a close multidisciplinary partnership in the exploration of natural product leads using combinatorial and medicinal chemistry, complete synthesis, combinatorial biochemistry, and nanotechnology. Natural product analysis that combines nanotechnology and analytical methods is a dominant strategy for identifying biologically active substances having distinct structures as well as modes of activity. Given nature's immeasurable diversity, it is obvious that chemical leads

\section{REFERENCES}

Abdelmohsen, U. R., Bayer, K., and Hentschel, U. (2014). Diversity, Abundance and Natural Products of marine Sponge-Associated Actinomycetes. Nat. Prod. Rep. 31, 381-399. doi:10.1039/c3np70111e

Abdollahpour-Alitappeh, M., Lotfinia, M., Gharibi, T., Mardaneh, J., Farhadihosseinabadi, B., Larki, P., et al. (2019). Antibody-drug Conjugates (ADCs) for Cancer Therapy: Strategies, Challenges, and Successes. J. Cel. Physiol. 234, 5628-5642. doi:10.1002/jcp.27419

AlAjmi, M. F., Rehman, M. T., Hussain, A., and Rather, G. M. (2018). Pharmacoinformatics Approach for the Identification of Polo-like Kinase-1 Inhibitors from Natural Sources as Anti-cancer Agents. Int. J. Biol. Macromolecules 116, 173-181. doi:10.1016/j.ijbiomac.2018.05.023

Aljofan, M., and Riethmacher, D. (2019). Anticancer Activity of Metformin: a Systematic Review of the Literature. Future Sci. OA 5, FSO410. doi:10.2144/fsoa-2019-0053

Amaral, M. E. A., Nery, L. R., Leite, C. E., de Azevedo Junior, W. F., and Campos, M. M. (2018). Pre-clinical Effects of Metformin and Aspirin on the Cell Lines of Different Breast Cancer Subtypes. Invest. New Drugs 36, 782-796. doi:10.1007/s10637-018-0568-y

Arba, M., Yamin, Ihsan, S., and Tjahjono, D. H. (2018). Computational Approach toward Targeting the Interaction of Porphyrin Derivatives with Bcl-2. J. App. Pharm. Sci. 8 (12), 060-066. capable of interacting with all therapeutic targets can be produced, indicating a greater potential for the production of highly effective therapeutic agents. Several technological advancements in the drug discovery fields will lead to speeding up the process of finding suitable drug candidates of natural origin that have potential anticancer activity. The multitarget approach of drug discovery has provided an attractive niche for medicinal scientists as it reduces the burden of the multidrug regime for cancer management and also reduces the side effects associated with them. Cutting edge analytical tools and bioinformatics especially machine learning will help in the process of drug discovery to find out the suitable hits in the early drug discovery phase of natural anticancer discovery. Natural phytochemicals continue to be a valuable substitute of scaffolds with high structural diversity and diverse antitumor activity that can be established directly or used as starting points for modeling into new therapeutics. The theranostic potential of such natural compounds is immense and we will witness much future research towards such theranostic agents of natural origin.

\section{AUTHOR CONTRIBUTIONS}

VPC conceived the plot; VPC researched the literature and wrote the manuscript along with other co-authors; VC made the figures and revised the manuscript with the help of YNE, KA and MC. YE and MC critically reviewed the manuscript. All authors reviewed the final manuscript and approved the same.

\section{ACKNOWLEDGMENTS}

We are very thankful to Dr. Chirag Patel (Assistant Professor, Department of Pharmacology, LMCP, Ahmadabad, India) for helping us in redesigning of Figure 5.

Bachmann, B. O., Van Lanen, S. G., and Baltz, R. H. (2014). Microbial Genome Mining for Accelerated Natural Products Discovery: Is a Renaissance in the Making? J. Ind. Microbiol. Biotechnol. 41, 175-184. doi:10.1007/s10295-013-1389-9

Barbuti, A., and Chen, Z.-S. (2015). Paclitaxel through the Ages of Anticancer Therapy: Exploring its Role in Chemoresistance and Radiation Therapy. Cancers 7, 2360-2371. doi:10.3390/cancers7040897

Beck, A., Goetsch, L., Dumontet, C., and Corvaïa, N. (2017). Strategies and Challenges for the Next Generation of Antibody-Drug Conjugates. Nat. Rev. Drug Discov. 16, 315-337. doi:10.1038/nrd.2016.268

Belwal, T., Bisht, A., Devkota, H. P., Ullah, H., Khan, H., Pandey, A., et al. (2020). Phytopharmacology and Clinical Updates of Berberis Species against Diabetes and Other Metabolic Diseases. Front. Pharmacol. 11, 41. doi:10.3389/ fphar.2020.00041

Bisen, P. S. (2016). Experimental and Computational Approaches in Leveraging Natural Compounds for Network Based Anti-cancer Medicine. J. Can. Sci. Res. 02, e103. doi:10.4172/2576-1447.1000e103

Boucher, I. W., McMillan, P. J., Gabrielsen, M., Akerman, S. E., Brannigan, J. A., Schnick, C., et al. (2006). Structural and Biochemical Characterization of a Mitochondrial Peroxiredoxin from Plasmodium Falciparum. Mol. Microbiol. 61, 948-959. doi:10.1111/j.1365-2958.2006.05303.x

Cerella, C., Muller, F., Gaigneaux, A., Radogna, F., Viry, E., Chateauvieux, S., et al. (2015). Early Downregulation of Mcl-1 Regulates Apoptosis Triggered by 
Cardiac Glycoside UNBS1450. Cell Death Dis. 6, e1782. doi:10.1038/ cddis.2015.134

Chakraborti, C. (2011). Vitamin D as a Promising Anticancer Agent. Indian J. Pharmacol. 43, 113-120. doi:10.4103/0253-7613.77335

Chandra, S. (2012). Endophytic Fungi: Novel Sources of Anticancer lead Molecules. Appl. Microbiol. Biotechnol. 95, 47-59. doi:10.1007/s00253-0124128-7

Charlop-Powers, Z., Milshteyn, A., and Brady, S. F. (2014). Metagenomic Small Molecule Discovery Methods. Curr. Opin. Microbiol. 19, 70-75. doi:10.1016/ j.mib.2014.05.021

Charmsaz, S., Prencipe, M., Kiely, M., Pidgeon, G., and Collins, D. (2018). Innovative Technologies Changing Cancer Treatment. Cancers 10, 208. doi:10.3390/cancers10060208

Chavda, V. P., Mohapatra, S. S., Ranjan, S., Dasgupta, N., Mishra, R. K., and Thomas, D. S. (2019). "Chapter 4 - Nanobased Nano Drug Delivery: A Comprehensive Review," in Micro And Nano Technologies. Elsevier, 69-92. doi:10.1016/B978-0-12-814029-1.00004-1

Chen, D., Dai, F., Chen, Z., Wang, S., Cheng, X., Sheng, Q., et al. (2016). Dimethoxy Curcumin Induces Apoptosis by Suppressing Survivin and Inhibits Invasion by Enhancing E-Cadherin in Colon Cancer Cells. Med. Sci. Monit. 22, 3215-3222. doi: $10.12659 / \mathrm{msm} .900802$

Chen, X., Chen, X., Zhang, X., Wang, L., Cao, P., Rajamanickam, V., et al. (2019). Curcuminoid B63 Induces ROS-Mediated Paraptosis-like Cell Death by Targeting TrxR1 in Gastric Cells. Redox Biol. 21, 101061. doi:10.1016/ j.redox.2018.11.019

Cheung, J. Y., Ong, R. C., Suen, Y. K., Ooi, V., Wong, H. N., Mak, T. C., et al. (2005). Polyphyllin D Is a Potent Apoptosis Inducer in Drug-Resistant HepG2 Cells. Cancer Lett. 217, 203-211. doi:10.1016/j.canlet.2004.06.042

Cova, T. F. G. G., Bento, D. J., and Nunes, S. C. C. (2019). Computational Approaches in Theranostics: Mining and Predicting Cancer Data. Pharmaceutics 11, 119. doi:10.3390/pharmaceutics11030119

Cragg, G. M., and Pezzuto, J. M. (2016). Natural Products as a Vital Source for the Discovery of Cancer Chemotherapeutic and Chemopreventive Agents. Med. Princ. Pract. 25, 41-59. doi:10.1159/000443404

Cutler, D. M. (2020). Early Returns From the Era of Precision Medicine. JAMA. 323, 109-110. doi:10.1001/jama.2019.20659

Dall'Acqua, S. (2014). Natural Products as Antimitotic Agents. Curr. Top. Med. Chem. 14, 2272-2285. doi:10.2174/1568026614666141130095311

Das, A. (2015). Anticancer Effect of AntiMalarial Artemisinin Compounds. Ann. Med. Health Sci. Res. 5, 93-102. doi:10.4103/2141-9248.153609

David, B., Grondin, Antonio., Schambel, Philippe., and Vitorino, Marc. (2020). Plant Natural Fragments, an Innovative Approach for Drug Discovery. Phytochem. Rev. 19, 1141-1156.

de Araújo, R. S. A., da Silva-Junior, E. F., de Aquino, T. M., Scotti, M. T., Ishiki, H. M., Scotti, L., et al. (2020). Computer-Aided Drug Design Applied to Secondary Metabolites as Anticancer Agents. Ctmc 20, 1677-1703. doi:10.2174/ 1568026620666200607191838

Dey, P., Kundu, A., Kumar, A., Gupta, M., Lee, B. M., Bhakta, T., et al. (2020). Analysis of Alkaloids (Indole Alkaloids, Isoquinoline Alkaloids, Tropane Alkaloids). Recent Adv. Nat. Prod. Anal., 505-567. doi:10.1016/B978-0-12-816455-6.00015-9

Elyashberg, M., and Argyropoulos, D. (2020). Computer Assisted Structure Elucidation (CASE): Current and Future Perspectives. Magn. Reson. Chem. 59, 669-690. doi:10.1002/mrc.5115

Elyashberg, M., Blinov, K., Molodtsov, S., Smurnyy, Y., Williams, A. J., and Churanova, T. (2009). Computer-assisted Methods for Molecular Structure Elucidation: Realizing a Spectroscopist's Dream. J. Cheminform. 1, 3. doi:10.1186/1758-2946-1-3

Florean, C., Schnekenburger, M., Lee, J. Y., Kim, K. R., Mazumder, A., Song, S., et al. (2016). Discovery and Characterization of Isofistularin-3, a Marine Brominated Alkaloid, as a New DNA Demethylating Agent Inducing Cell Cycle Arrest and Sensitization to TRAIL in Cancer Cells. Oncotarget. 7, 24027-24049. doi:10.18632/oncotarget.8210

Garofalo, M., Grazioso, G., Cavalli, A., and Sgrignani, J. (2020). How Computational Chemistry and Drug Delivery Techniques Can Support the Development of New Anticancer Drugs. Molecules 25, 1756. doi:10.3390/ molecules 25071756
Gupta, P., Wright, S. E., Kim, S.-H., and Srivastava, S. K. (2014). Phenethyl Isothiocyanate: a Comprehensive Review of Anti-cancer Mechanisms. Biochim. Biophys. Acta (Bba) - Rev. Cancer 1846, 405-424. doi:10.1016/j.bbcan.2014.08.003

Harn, Y.-C., Su, B.-H., Ku, Y.-L., Lin, O. A., Chou, C.-F., and Tseng, Y. J. (2017). NP-StructurePredictor: Prediction of Unknown Natural Products in Plant Mixtures. J. Chem. Inf. Model. 57, 3138-3148. doi:10.1021/acs.jcim.7b00565

Holohan, C., Van Schaeybroeck, S., Longley, D. B., and Johnston, P. G. (2013). Cancer Drug Resistance: An Evolving Paradigm. Nat. Rev. Cancer 13, 714-726. doi:10.1038/nrc3599

Hoseini-Ghahfarokhi, M., Mirkiani, S., Mozaffari, N., Abdolahi Sadatlu, M. A., Ghasemi, A., Abbaspour, S., et al. (2020). Applications of Graphene and Graphene Oxide in Smart Drug/Gene Delivery: Is the World Still Flat?. Ijn 15, 9469-9496. doi:10.2147/IJN.S265876

Jampilek, J., and Kralova, K. (2021). Advances in Drug Delivery Nanosystems Using Graphene-Based Materials and Carbon Nanotubes. Materials 14, 1059. doi:10.3390/ma14051059

Khalifa, S. A. M., Elias, N., Farag, M. A., Chen, L., Saeed, A., Hegazy, M.-E. F., et al. (2019). Marine Natural Products: A Source of Novel Anticancer Drugs. Mar. Drugs 17, 491. doi:10.3390/md17090491

Kind, T., and Fiehn, O. (2010). Advances in Structure Elucidation of Small Molecules Using Mass Spectrometry. Bioanal. Rev. 2, 23-60. doi:10.1007/ s12566-010-0015-9

Kljun, J., and Turel, I. (2017). $\beta$-Diketones as Scaffolds for Anticancer Drug Design from Organic Building Blocks to Natural Products and Metallodrug Components. Eur. J. Inorg. Chem. 2017, 1655-1666. doi:10.1002/ejic.2016013142017

Ko, J.-H., Sethi, G., Um, J.-Y., Shanmugam, M. K., Arfuso, F., Kumar, A. P., et al. (2017). The Role of Resveratrol in Cancer Therapy. Ijms 18, 2589. doi:10.3390/ ijms 18122589

Koos, M. R. M., Navarro-Vázquez, A., Anklin, C., and Gil, R. R. (2020). ComputerAssisted 3D Structure Elucidation (CASE-3D): The Structural Value of $2 \mathrm{~J} \mathrm{CH}$ in Addition to $3 \mathrm{~J} \mathrm{CH}$ Coupling Constants. Angew. Chem. Int. Ed. 59, 3938-3941. doi:10.1002/anie.201915103

Korga, A., Ostrowska, M., Jozefczyk, A., Iwan, M., Wojcik, R., Zgorka, G., et al. (2019). Apigenin and Hesperidin Augment the Toxic Effect of Doxorubicin against HepG2 Cells. BMC Pharmacol. Toxicol. 20, 22. doi:10.1186/s40360-0190301-2

Krzyszczyk, P., Acevedo, A., Davidoff, E. F., Timmins, L. M., Marrero-Berrios, I., Patel, M., et al. (2018). The Growing Role of Precision and Personalized Medicine for Cancer Treatment. Technol. 6, 79-100. doi:10.1142/ S2339547818300020

Kumar, M. S., and Adki, K. M. (2018). Marine Natural Products for Multi-Targeted Cancer Treatment: A Future Insight. Biomed. Pharmacother. 105, 233-245. doi:10.1016/j.biopha.2018.05.142

Kumar, P. (2018). Recent Advancement in Cancer Treatment. Elsevier Inc, 621-651. doi:10.1016/B978-0-12-813669-0.00016-6

Kuntz, E. M., Baquero, P., Michie, A. M., Dunn, K., Tardito, S., Holyoake, T. L., et al. (2017). Targeting Mitochondrial Oxidative Phosphorylation Eradicates Therapy-Resistant Chronic Myeloid Leukemia Stem Cells. Nat. Med. 23, 1234-1240. doi:10.1038/nm.4399

Kwak, T. W., Park, S.-B., Kim, H.-J., Jeong, Y.-I., and Kang, D. H. (2017). Anticancer Activities of Epigallocatechin-3-Gallate against Cholangiocarcinoma Cells. Ott 10, 137-144. doi:10.2147/OTT.S112364

Lee, I.-C., and Choi, B. (2016). Withaferin-A-A Natural Anticancer Agent with Pleitropic Mechanisms of Action. Ijms 17, 290. doi:10.3390/ijms17030290

Lee, J., Sul, J., Park, J., Lee, M., Cha, E., and Ko, Y. (2019). Honokiol Induces Apoptosis and Suppresses Migration and Invasion of Ovarian Carcinoma Cells via AMPK/mTOR Signaling Pathway. Int. J. Mol. Med. 43, 1969-1978. doi:10.3892/ijmm.2019.4122

Li, A., and Bergan, R. C. (2020). Clinical Trial Design: Past, Present, and Future in the Context of Big Data and Precision Medicine. Cancer 126, 4838-4846. doi:10.1002/cncr.33205

Li, Q. (2020). Application of Fragment-Based Drug Discovery to Versatile Targets. Front. Mol. Biosci. 7, 180. doi:10.3389/fmolb.2020.00180

Li, X., Chu, S., Lin, M., Gao, Y., Liu, Y., Yang, S., et al. (2020). Anticancer Property of Ginsenoside Rh2 from Ginseng. Eur. J. Med. Chem. 203, 112627. doi:10.1016/ j.ejmech.2020.112627 
Liang, J.-W., Wang, M.-Y., Wang, S., Li, X.-Y., and Meng, F.-H. (2019). FragmentBased Structural Optimization of a Natural Product Itampolin A as a P38a Inhibitor for Lung Cancer. Mar. Drugs 17, 53. doi:10.3390/md17010053

Lin, L.-G., Xie, H., Li, H.-L., Tong, L.-J., Tang, C.-P., Ke, C.-Q., et al. (2008). Naturally Occurring Homoisoflavonoids Function as Potent Protein Tyrosine Kinase Inhibitors by C-Src-Based High-Throughput Screening. J. Med. Chem. 51, 4419-4429. doi:10.1021/jm701501x

Ling, H., Yang, H., Tan, S.-H., Chui, W.-K., and Chew, E.-H. (2010). 6-Shogaol, an Active Constituent of Ginger, Inhibits Breast Cancer Cell Invasion by Reducing Matrix Metalloproteinase-9 Expression via Blockade of Nuclear Factor- $\mathrm{Kb}$ Activation. Br. J. Pharmacol. 161, 1763-1777. doi:10.1111/j.14765381.2010.00991.x

Ling, M. T., Luk, S. U., Al-Ejeh, F., and Khanna, K. K. (2012). Tocotrienol as a Potential Anticancer Agent. Carcinogenesis 33, 233-239. doi:10.1093/carcin/ bgr261

Liu, K. K.-C., Bagrodia, S., Bailey, S., Cheng, H., Chen, H., Gao, L., et al. (2010). 4-Methylpteridinones as Orally Active and Selective PI3K/mTOR Dual Inhibitors. Bioorg. Med. Chem. Lett. 20, 6096-6099. doi:10.1016/ j.bmcl.2010.08.045

Liu, M., and Quinn, R. J. (2019). Fragment-based Screening with Natural Products for Novel Anti-parasitic Disease Drug Discovery. Expert Opin. Drug Discov. 14, 1283-1295. doi:10.1080/17460441.2019.1653849

Lu, M.-D., Li, L.-Y., Li, P.-H., You, T., Wang, F.-H., Sun, W.-J., et al. (2017). Gossypol Induces Cell Death by Activating Apoptosis and Autophagy in HT-29 Cells. Mol. Med. Rep. 16, 2128-2132. doi:10.3892/mmr.2017.6804

Ma, Z., Wan, H., Wang, W., Zhang, X., Uno, T., Yang, Q., et al. (2019). A Theranostic Agent for Cancer Therapy and Imaging in the Second NearInfrared Window. Nano Res. 12, 273-279. doi:10.1007/s12274-018-2210-x

Majnooni, M. B., Fakhri, S., Smeriglio, A., Trombetta, D., Croley, C. R., Bhattacharyya, P., et al. (2019). Antiangiogenic Effects of Coumarins against Cancer: From Chemistry to Medicine. Molecules 24, 4278. doi:10.3390/ molecules 24234278

Maruca, A., Rocca, R., Catalano, R., Mesiti, F., Costa, G., Lanzillotta, D., et al. (2020). Natural Products Extracted from Fungal Species as New Potential Anticancer Drugs: A Structure-Based Drug Repurposing Approach Targeting HDAC7. Molecules 25, 5524. doi:10.3390/molecules25235524

Mazumder, A., Cerella, C., and Diederich, M. (2018). Natural Scaffolds in Anticancer Therapy and Precision Medicine. Biotechnol. Adv. 36, 1563-1585. doi:10.1016/j.biotechadv.2018.04.009

Mullard, A. (2014a). 2013 FDA Drug Approvals. Nat. Rev. Drug Discov. 13, 85-89. doi:10.1038/nrd4239

Mullard, A. (2014b). New Drugs Cost US\$2.6 Billion to Develop. Nat. Rev. Drug Discov. 13, 877. doi:10.1038/nrd4507

Murray, C. W., and Rees, D. C. (2009). The Rise of Fragment-Based Drug Discovery. Nat. Chem 1, 187-192. doi:10.1038/nchem.217

Neag, M. A., Mocan, A., Echeverría, J., Pop, R. M., Bocsan, C. I., Crişan, G., et al. (2018). Berberine: Botanical Occurrence, Traditional Uses, Extraction Methods, and Relevance in Cardiovascular, Metabolic, Hepatic, and Renal Disorders. Front. Pharmacol. 9, 557. doi:10.3389/fphar.2018.00557

Newman, D. J., and Cragg, G. M. (2012). Natural Products as Sources of New Drugs over the 30 Years from 1981 to 2010. J. Nat. Prod. 75, 311-335. doi:10.1021/ np200906s

NIH (2021). Cancer. Available at: https://www.cancer.gov/publications/ dictionaries/cancer-terms/def/cancer (Accessed April 25, 2021).

Nugroho, A. E., and Morita, H. (2019). Computationally-assisted Discovery and Structure Elucidation of Natural Products. J. Nat. Med. 73, 687-695. doi:10.1007/s11418-019-01321-8

Ontikatze, T., Rudner, J., Handrick, R., Belka, C., and Jendrossek, V. (2014). Dihydroartemisinin Is a Hypoxia-Active Anti-cancer Drug in Colorectal Carcinoma Cells. Front. Oncol. 4, 116. doi:10.3389/fonc.2014.00116

Ortiz-Hidalgo, C., and Pina-Oviedo, S. (2019). Hematoxylin: Mesoamerica's Gift to Histopathology. Palo de Campeche (Logwood Tree), Pirates' Most Desired Treasure, and Irreplaceable Tissue Stain. Int. J. Surg. Pathol. 27, 4-14. doi:10.1177/1066896918787652

Parsai, S., Keck, R., Skrzypczak-Jankun, E., and Jankun, J. (2014). Analysis of the Anticancer Activity of Curcuminoids, Thiotryptophan and 4-phenoxyphenol Derivatives. Oncol. Lett. 7, 17-22. doi:10.3892/ol.2013.1679
Petrelli, A., and Valabrega, G. (2009). Multitarget Drugs: The Present and the Future of Cancer Therapy. Expert Opin. Pharmacother. 10, 589-600. doi:10.1517/14656560902781907

Peyvandipour, A., Saberian, N., Shafi, A., Donato, M., and Draghici, S. (2018). A Novel Computational Approach for Drug Repurposing Using Systems Biology. Bioinformatics 34, 2817-2825. doi:10.1093/bioinformatics/bty133

Pfirschke, C., Engblom, C., Rickelt, S., Cortez-Retamozo, V., Garris, C., Pucci, F., et al. (2016). Immunogenic Chemotherapy Sensitizes Tumors to Checkpoint Blockade Therapy. Immun. 44, 343-354. doi:10.1016/j.immuni.2015.11.024

Pradeep, C. R., and Kuttan, G. (2004). Piperine Is a Potent Inhibitor of Nuclear Factor- Kb (NF-Kb), C-Fos, CREB, ATF-2 and Proinflammatory Cytokine Gene Expression in B16F-10 Melanoma Cells. Int. Immunopharmacology 4, 1795-1803. doi:10.1016/j.intimp.2004.08.005

Ramsay, R. R., Popovic-Nikolic, M. R., Nikolic, K., Uliassi, E., and Bolognesi, M. L. (2018). A Perspective on Multi-target Drug Discovery and Design for Complex Diseases. Clin. Translational Med. 7, 3. doi:10.1186/s40169-017-0181-2

Rayburn, E., Ezell, S. J., and Zhang, R. (2009). Anti-Inflammatory Agents for Cancer Therapy. Mol. Cel. Pharmacol. 1, 29-43. doi:10.4255/ mcpharmacol.09.05

Rinschen, M. M., Ivanisevic, J., Giera, M., and Siuzdak, G. (2019). Identification of Bioactive Metabolites Using Activity Metabolomics. Nat. Rev. Mol. Cel Biol. 20, 353-367. doi:10.1038/s41580-019-0108-4

Rosli, N. F., Fojtů, M., Fisher, A. C., and Pumera, M. (2019). Graphene Oxide Nanoplatelets Potentiate Anticancer Effect of Cisplatin in Human Lung Cancer Cells. Langmuir 35, 3176-3182. doi:10.1021/acs.langmuir.8b03086

Sahebkar, A. (2016). Curcumin. Integr. Cancer Ther. 15, 333-334. doi:10.1177/ 1534735415624139

Setlow, R. B. (2001). Human Cancer: Etiologic Agents/dose Responses/DNA Repair/cellular and Animal Models. Mutat. Research/Fundamental Mol. Mech. Mutagenesis 477, 1-6. doi:10.1016/s0027-5107(01)00090-2

Shahinozzaman, M., Ishii, T., Ahmed, S., Halim, M. A., and Tawata, S. (2020). A Computational Approach to Explore and Identify Potential Herbal Inhibitors for the P21-Activated Kinase 1 (PAK1). J. Biomol. Struct. Dyn. 38, 3514-3526. doi:10.1080/07391102.2019.1659855

Shailaja, V. L., Christina, V. S., Mohanapriya, C. D., Sneha, P., Lakshmi Sundaram, R., Magesh, R., et al. (2019). A Natural Anticancer pigment,Pheophytin A,from a Seagrass Acts as a High Affinity Human Mitochondrial Translocator Protein (TSPO) Ligand, In Silico, to Reduce Mitochondrial Membrane Potential $(\Delta \psi)$ in Adenocarcinomic A549 Cells. Phytomedicine 61, 152858. doi:10.1016/ j.phymed.2019.152858

Sharma, R., Mody, N., Agrawal, U., and Vyas, S. P. (2017). Theranostic Nanomedicine; A Next Generation Platform for Cancer Diagnosis and Therapy. Mrmc 17, 1746-1757. doi:10.2174/1389557516666160219122524

Shi, J., Kantoff, P. W., Wooster, R., and Farokhzad, O. C. (2017). Cancer Nanomedicine: Progress, Challenges and Opportunities. Nat. Rev. Cancer 17, 20-37. doi:10.1038/nrc.2016.108

Shi, J., Li, J., Xu, Z., Chen, L., Luo, R., Zhang, C., et al. (2020). Celastrol: A Review of Useful Strategies Overcoming its Limitation in Anticancer Application. Front. Pharmacol. 11, 558741. doi:10.3389/fphar.2020.558741

Silva, C. O., Pinho, J. O., Lopes, J. M., Almeida, A. J., Gaspar, M. M., and Reis, C. (2019). Current Trends in Cancer Nanotheranostics: Metallic, Polymeric, and Lipid-Based Systems. Pharmaceutics 11, 22. doi:10.3390/ pharmaceutics11010022

Singh, N., and Sharma, B. (2018). Toxicological Effects of Berberine and Sanguinarine. Front. Mol. Biosci. 5, 21. doi:10.3389/fmolb.2018.00021

Sivasankarapillai, V. S., Madhu Kumar Nair, R., Rahdar, A., Bungau, S., Zaha, D. C., Aleya, L., et al. (2020). Overview of the Anticancer Activity of Withaferin A, an Active Constituent of the Indian Ginseng Withania Somnifera. Environ. Sci. Pollut. Res. 27, 26025-26035. doi:10.1007/s11356-020-09028-0

Soong, R., Pautler, B. G., Moser, A., Jenne, A., Lysak, D. H., Adamo, A., et al. (2020). CASE (Computer-Assisted Structure Elucidation) Study for an Undergraduate Organic Chemistry Class. J. Chem. Educ. 97, 855-860. doi:10.1021/ acs.jchemed.9b00498

Su, B.-H., Shen, M.-Y., Harn, Y.-C., Wang, S.-Y., Schurz, A., Lin, C., et al. (2017). An Efficient Computer-Aided Structural Elucidation Strategy for Mixtures Using an Iterative Dynamic Programming Algorithm. J. Cheminform. 9, 57. doi:10.1186/s13321-017-0244-9 
Tay, K.-C., Tan, L. T.-H., Chan, C. K., Hong, S. L., Chan, K.-G., Yap, W. H., et al. (2019). Formononetin: A Review of its Anticancer Potentials and Mechanisms. Front. Pharmacol. 10, 820. doi:10.3389/fphar.2019.00820

Taylor, W. F., Moghadam, S. E., Moridi Farimani, M., N. Ebrahimi, S., Tabefam, M., and Jabbarzadeh, E. (2019). A Multi-Targeting Natural Compound with Growth Inhibitory and Anti-angiogenic Properties Re-sensitizes Chemotherapy Resistant Cancer. PLoS One 14, e0218125-17. doi:10.1371/ journal.pone.0218125

Teiten, M.-H., Dicato, M., and Diederich, M. (2014). Hybrid Curcumin Compounds: a New Strategy for Cancer Treatment. Molecules 19, 20839-20863. doi:10.3390/molecules 191220839

Teiten, M.-H., Eifes, S., Dicato, M., and Diederich, M. (2010). Curcumin-The Paradigm of a Multi-Target Natural Compound with Applications in Cancer Prevention and Treatment. Toxins 2, 128-162. doi:10.3390/toxins2010128

Tomeh, M., Hadianamrei, R., and Zhao, X. (2019). A Review of Curcumin and its Derivatives as Anticancer Agents. Ijms 20, 1033. doi:10.3390/ijms20051033

Tripathi, S. K., and Biswal, B. K. (2020). Piperlongumine, a Potent Anticancer Phytotherapeutic: Perspectives on Contemporary Status and Future Possibilities as an Anticancer Agent. Pharmacol. Res. 156, 104772. doi:10.1016/j.phrs.2020.104772

Wang, L.-S., and Stoner, G. D. (2008). Anthocyanins and Their Role in Cancer Prevention. Cancer Lett. 269, 281-290. doi:10.1016/j.canlet.2008.05.020

Wang, Y., Liu, Y., Du, X., Ma, H., and Yao, J. (2020). The Anti-cancer Mechanisms of Berberine: A Review. Cmar 12, 695-702. doi:10.2147/CMAR.S242329

Ward, C. C., Kleinman, J. I., Brittain, S. M., Lee, P. S., Chung, C. Y. S., Kim, K., et al. (2019). Covalent Ligand Screening Uncovers a RNF4 E3 Ligase Recruiter for Targeted Protein Degradation Applications. ACS Chem. Biol. 14, 2430-2440. doi:10.1021/acschembio.8b01083

Weng, J.-R., Tsai, C.-H., Kulp, S. K., and Chen, C.-S. (2008). Indole-3-carbinol as a Chemopreventive and Anti-cancer Agent. Cancer Lett. 262, 153-163. doi:10.1016/j.canlet.2008.01.033

Who (2021a). Cancer Today. Available at: https:/gco.iarc.fr/today/.

Who (2021b). WHO FactSheets: Cancer. 3 March 2021. Available at: https://www. who.int/news-room/fact-sheets/detail/cancer (Accessed April 25, 2021).
Wilken, R., Veena, M. S., Wang, M. B., and Srivatsan, E. S. (2011). Curcumin: A Review of Anti-cancer Properties and Therapeutic Activity in Head and Neck Squamous Cell Carcinoma. Mol. Cancer 10, 12. doi:10.1186/14764598-10-12

Wogan, G. N., Hecht, S. S., Felton, J. S., Conney, A. H., and Loeb, L. A. (2004). Environmental and Chemical Carcinogenesis. Semin. Cancer Biol. 14, 473-486. doi:10.1016/j.semcancer.2004.06.010

Xu, J.-Y., Meng, Q.-H., Chong, Y., Jiao, Y., Zhao, L., Rosen, E. M., et al. (2012). Sanguinarine Inhibits Growth of Human Cervical Cancer Cells through the Induction of Apoptosis. Oncol. Rep. 28, 2264-2270. doi:10.3892/or.2012.2024

Yang, W., Deng, X., Huang, W., Qing, X., and Shao, Z. (2019). The Physicochemical Properties of Graphene Nanocomposites Influence the Anticancer Effect. J. Oncol. 2019, 1-10. doi:10.1155/2019/7254534

Zhang, S., Gao, Q., Li, W., Zhu, L., Shang, Q., Feng, S., et al. (2019). Shikonin Inhibits Cancer Cell Cycling by Targeting Cdc25s. BMC Cancer 19, 20. doi:10.1186/s12885-018-5220-x

Conflict of Interest: The authors declare that the research was conducted in the absence of any commercial or financial relationships that could be construed as a potential conflict of interest.

Publisher's Note: All claims expressed in this article are solely those of the authors and do not necessarily represent those of their affiliated organizations, or those of the publisher, the editors and the reviewers. Any product that may be evaluated in this article, or claim that may be made by its manufacturer, is not guaranteed or endorsed by the publisher.

Copyright (C) 2021 Chavda, Ertas, Walhekar, Modh, Doshi, Shah, Anand and Chhabria. This is an open-access article distributed under the terms of the Creative Commons Attribution License (CC BY). The use, distribution or reproduction in other forums is permitted, provided the original author(s) and the copyright owner(s) are credited and that the original publication in this journal is cited, in accordance with accepted academic practice. No use, distribution or reproduction is permitted which does not comply with these terms. 